\title{
The Knowledge and Attitude of Universitas Muhammadiyah Magelang Pharmacy Students on National Health Programs-a Descriptive Study
}

\author{
Prasojo Pribadi $^{1 *}$, Rayi Citra Ayu Pangestuti ${ }^{1}$, Heni Lutfiyati ${ }^{1}$, Elmiawati Latifah ${ }^{1}$, \\ Setyo Budi Santoso ${ }^{1}$
}

${ }^{1}$ Faculty of Health Science, Universitas Muhammadiyah Magelang, Magelang, Indonesia

${ }^{*}$ Corresponding author. Email: prasojopribadi@ummgl.ac.id

\begin{abstract}
The important role of pharmacists in the community in disseminating the National Health Programs is as an effort to educate healthy lifestyles to the community. This paper aims to assessing the knowledge and attitude of Universitas Muhammadiyah Magelang pharmacy students on National Health Programs. Methods: This research is a cross-sectional survey. A total of 124 respondents were used in this study. This study carried out from August 2019 were used convenience sampling technique. Results: Of all student pharmacy programs group (Pharmacy Diploma Program and Pharmacy Bachelor Program), 76.6\% of pharmacy students feel that their current knowledge is not sufficient to be an active part of National Health Programs. 64.5\% of pharmacy students believe that they play an important role in National Health Programs. 97.6\% of pharmacy students are willing to take on professional roles and $98.4 \%$ wanted to learn more about National Health Programs. There is no relationship of pharmacy programs on knowledge and attitudes towards the national health program of National Health Programs. Health education institutions as the pioneer of health workers must equip their students with sufficient knowledge about national health programs so as to increase their role and desire to participate in the National Health Programs.
\end{abstract}

Keywords: knowledge, attitude, pharmacy students, National Health Programs

\section{INTRODUCTION}

Human Development Index (HDI) is a composite indicator of three development sector indicators: education, health, and economy. Indonesia's HDI in 2010 was 108 th, while in 2011 down to rank 124th [1]. This fact shows the declining quality of life of Indonesian people. According to Susilo cit Sulaeman [1], Indonesia has repeatedly been ranked as a country which is slow in achieving the MDGs. This is indicated by the high maternal and under-five mortality rates, the high rate of transmission of HIV/AIDS, the low fulfillment of clean water and poor sanitation, the lack of recognition of community initiatives, the Indonesian government has never encouraged a shared sense of ownership of the MDGs to its people [1].

The health communication campaign is essentially a government effort aimed at raising awareness, willingness and ability to live healthy lives for everyone in order to realize the highest degree of public health [2]. One of the government's efforts to overcome health problems is through the Healthy Life Society Movement (GERMAS) activity. The Healthy Life Society Movement (GERMAS) is as an effort to educate healthy lifestyles to the community [3]. This is a systematic planned action carried out simultaneously by all components of this country with their own awareness and will and ability to live healthy to improve the quality of life [4]. The Government through the
Directorate General of Pharmaceutical Development and Medical Devices in the series of the Healthy Life Society Movement, also launched Gerakan Masyarakat Cerdas Menggunakan Obat "Gema Cermat" [5].

Health problems and disease problems, not solely stem from individual negligence, negligence of the family, negligence of the group or community. Most of the illnesses suffered by community generally stem from ignorance and misunderstanding of various health information received [6]. Based on data from the Basic Health Research (Riskesdas) in 2013, the level of public awareness of health is only 20 percent where current health problems are the result of unhealthy living problems coupled with an unhealthy environment and also clean water which is still inadequate in some places [7]. This condition is not only the responsibility of the government or the health sector, collaboration is needed between relevant stakeholders such as health workers (midwives, nurses, doctors, pharmacists, etc.), health education institutions in efforts to improve health in Indonesia [8]. Health workers are required to take a professional role in providing health service, therefore the community will be more active in conducting routine checks [9].

The role of students in realizing a healthy society also cannot be ruled out, by playing an active role in the national health program campaigned by the government can accelerate the increase in the human development index. The desire to be involved and play an active role in national health programs cannot be separated from the influence of 
the knowledge and attitudes of students themselves. However, to date research related to measuring students' knowledge and attitudes towards the national health program is still limited. The purpose of this study was to determine the knowledge and attitudes of pharmacy students about the national health program at the University of Muhammadiyah Magelang.

\section{METHOD}

\subsection{Study Design and Data Collection}

A cross-sectional survey was carried out from September 2019 at the Faculty of Health Sciences, Universitas Muhammadiyah Magelang, Central Java, Indonesia. A total of 124 respondents were used in this study. Inclusion criteria in this study were active pharmacy students from 2017-2019.

\subsection{Survey Instrument}

The research were used questionnaire adapted from Prasada [10]. The structured questionnaire contains questions related to the research variables. The first part contained demographic information, the second part contained students' job or work area preferences after completing their pharmacy education, the third part comprised of questions related to knowledge and attitude among Pharmacy Diploma Program and Pharmacy Bachelor Program students on National Health Programs. Statement items in the questionnaire were tested by conducting a pilot test on 10 respondents.

\subsection{Data Analysis}

Data analysis were used cross tabulation to find out the relationship between the pharmacy education program students' group (Pharmacy Diploma Program and Pharmacy Bachelor Program) with knowledge and attitude on national health programs. Data is analysed using SPSS version 21.0.

\section{RESULTS AND DISCUSSION}

Table 1 Demographic data of students

\begin{tabular}{|lccc|}
\hline Variable & $\begin{array}{c}\text { Pharmacy Diploma Program } \\
(\mathbf{n = 3 5})\end{array}$ & $\begin{array}{c}\text { Pharmacy Bachelor Program } \\
(\mathbf{n}=\mathbf{8 9})\end{array}$ & $\begin{array}{c}\text { Total } \\
(\mathbf{n}=\mathbf{1 2 4})\end{array}$ \\
\hline Gender & & & \\
Female & $31(88.57)$ & $75(84.27)$ & $106(85.48)$ \\
Male & $4(11.43)$ & $14(15.73)$ & $18(14.52)$ \\
Age & & & \\
19-22 & $28(80)$ & $79(88.76)$ & $107(86.29)$ \\
$23-27$ & $4(11.43)$ & $7(7.87)$ & $11(8.87)$ \\
$>27$ & $3(8.57)$ & $3(3.37)$ & $6(4.84)$ \\
Year of students & $1(2.86)$ & $1(1.12)$ & $1(0.81)$ \\
I & $1(2.86)$ & $40(44.94)$ & $41(33.06)$ \\
II & $33(94.29)$ & $20(22.47)$ & $21(16.94)$ \\
III & $0(0)$ & $28(31.46)$ & $61(49.19)$ \\
IV & & & \\
\hline
\end{tabular}

Table 2 Work area preferences of student after completing pharmacy education

\begin{tabular}{|lccc|}
\hline \multicolumn{1}{c}{ Question } & \multicolumn{3}{c|}{ Response, n(\%) } \\
\cline { 2 - 4 } & $\begin{array}{c}\text { Total } \\
(\mathbf{n = 1 2 4})\end{array}$ & $\begin{array}{c}\text { Pharmacy Diploma } \\
\text { Program }\end{array}$ & $\begin{array}{c}\text { Pharmacy Bachelor } \\
\text { Program }\end{array}$ \\
\hline Community Pharmacy & $18(14.52)$ & $3(8.57)$ & $15(16.85)$ \\
Hospital Pharmacy & $49(39.52)$ & $21(60)$ & $28(31.46)$ \\
Drug Manufacturing Industry & $19(15.32)$ & $3(8.57)$ & $16(17.98)$ \\
Research and Development & $2(1.61)$ & $0(0)$ & $2(2.25)$ \\
Regulatory officer in government & $21(16.94)$ & $6(17.14)$ & $15(16.85)$ \\
Higher studies & $7(5.65)$ & $0(0)$ & $7(7.87)$ \\
Marketing & $1(0.81)$ & $0(0)$ & $1(1.12)$ \\
Any other, please specify & $7(5.65)$ & $2(5.71)$ & $5(5.62)$ \\
\hline
\end{tabular}

Most of the total 124 respondents, $18(14.52 \%)$ were male and $106(85.48 \%)$ were female students. Most of the respondents came from the Pharmacy Bachelor Program as much as $71.8 \%$ while the remaining Pharmacy Diploma Program as much as $28.2 \%$ at the Faculty of Health
Sciences, Muhammadiyah University, Magelang. In this study, the majority of respondent ages were between 19-22 years (Table 1). Student job discipline preferences after completing the pharmacy education program are: hospitals 
(39.52\%), regulatory officials in government (16.94\%) and the drug manufacturing industry $(15.32 \%)$. (Table 2$)$.

Table 3 Pharmacy student's perceived knowledge in national health programs

\begin{tabular}{|c|c|c|c|c|}
\hline \multirow[b]{2}{*}{ Question } & \multicolumn{4}{|c|}{ Response, n (\%) } \\
\hline & $\begin{array}{c}\text { Total } \\
(\mathrm{n}=124)\end{array}$ & $\begin{array}{c}\text { Pharmacy Diploma } \\
\text { Program }(n=35) \\
\end{array}$ & $\begin{array}{c}\text { Pharmacy } \\
\text { Bachelor Program }\end{array}$ & $\begin{array}{c}\text { p- } \\
\text { value* }\end{array}$ \\
\hline \multicolumn{5}{|l|}{$\begin{array}{l}\text { In your pharmacy curriculum, have you been } \\
\text { studying about National Health Policy? }\end{array}$} \\
\hline Yes & $73(58.9)$ & $23(65.7)$ & $50(56.2)$ & 0.331 \\
\hline No & $51(41.1)$ & $12(34.3)$ & $39(43.8)$ & \\
\hline \multicolumn{5}{|l|}{$\begin{array}{l}\text { In your pharmacy curriculum, have you been } \\
\text { studying pharmaceutical policy? }\end{array}$} \\
\hline Yes & $106(85.5)$ & $33(94.3)$ & $73(82)$ & 0.081 \\
\hline No & $18(14.5)$ & $2(5.7)$ & $16(18)$ & \\
\hline \multicolumn{5}{|l|}{ Do you know Indonesia's National Public Health } \\
\hline Yes, I know well & $4(3.2)$ & $2(5.7)$ & $2(2.2)$ & 0.631 \\
\hline Yes, I know to some extent & $55(44.4)$ & $16(45.7)$ & $39(43.8)$ & \\
\hline Yes, I have heard, but don't know the contents & $47(37.9)$ & $11(31.4)$ & $36(40.4)$ & \\
\hline No, I have never heard about them & $18(14.5)$ & $6(17.1)$ & $12(13.5)$ & \\
\hline \multicolumn{5}{|l|}{$\begin{array}{l}\text { Have you attendd lectures or completed any courses } \\
\text { that provide information about National Public } \\
\text { Health Programs? }\end{array}$} \\
\hline Yes & $59(47.6)$ & $19(54.3)$ & $40(44.9)$ & 0.348 \\
\hline No & $65(52.4)$ & $16(45.7)$ & $49(55.1)$ & \\
\hline \multicolumn{5}{|l|}{$\begin{array}{l}\text { Is the time to studing aspects of public health is } \\
\text { sufficient? }\end{array}$} \\
\hline Yes & $66(53.2)$ & $19(54.3)$ & $47(52.8)$ & 0.882 \\
\hline No & $58(46.8)$ & $16(45.7)$ & $42(47.2)$ & \\
\hline \multicolumn{5}{|l|}{$\begin{array}{l}\text { Do you have adequate knowledge to take part in } \\
\text { National Public Health Programs according to your } \\
\text { pharmacy curriculum? }\end{array}$} \\
\hline Yes & $61(49.2)$ & $16(45.7)$ & $45(50.6)$ & 0.627 \\
\hline No & $63(50.8)$ & $19(54.3)$ & $44(49.4)$ & \\
\hline \multicolumn{5}{|l|}{$\begin{array}{l}\text { Have you studied about disease prevention and } \\
\text { dissemination of information in National Public } \\
\text { Health Programs? }\end{array}$} \\
\hline Yes & $66(53.2)$ & $22(62.9)$ & $44(49.4)$ & 0.178 \\
\hline No & $58(46.8)$ & $13(37.1)$ & $45(50.6)$ & \\
\hline \multicolumn{5}{|l|}{$\begin{array}{l}\text { Is it important to know about National Public Health } \\
\text { Programs for the pharmacists? }\end{array}$} \\
\hline Yes & $123(99.2)$ & $34(97.1)$ & $89(100)$ & 0.109 \\
\hline No & $1(0.8)$ & $1(2.9)$ & 0 & \\
\hline
\end{tabular}

Students' perceptions of national public health programs are shown in Table 3 . As many as $99.2 \%$ of students agreed that it was important to know the national public health program for pharmacists. $53.2 \%$ of students stated that they had learned about disease prevention, dissemination of health information and the time spent studying public health aspects in the pharmacy education curriculum was deemed sufficient. $41.1 \%$ of students stated that they had not studied national health policy and $85.5 \%$ of students had studied pharmaceutical policy. The results of cross tabulation analysis shows that there is no relationship between the pharmacy education program group (Pharmacy Diploma Program and Pharmacy Bachelor Program) on perceived knowledge in the national health program ( $p$-value $>0.05$ ). Pharmacy Diploma Program and Pharmacy Bachelor Program have the same views and understanding of their role in national health programs and both have positive responses to learn more about national health programs. 
Table 4 Pharmacy student's attitude on National Health Programs

\begin{tabular}{|c|c|c|c|c|}
\hline \multirow[b]{2}{*}{ Question } & \multicolumn{4}{|c|}{ Response, n(\%) } \\
\hline & $\begin{array}{c}\text { Total } \\
(n=124)\end{array}$ & $\begin{array}{c}\text { Pharmacy } \\
\text { Diploma } \\
\text { Program } \\
(n=35)\end{array}$ & $\begin{array}{c}\text { Pharmacy } \\
\text { Bachelor } \\
\text { Program } \\
(n=89)\end{array}$ & p-value* \\
\hline $\begin{array}{l}\text { Do you think that it is important to include National Public Health } \\
\text { Programs in curriculum of pharmacy education programs? } \\
\text { Very important } \\
\text { Important } \\
\text { Unimportant } \\
\text { Of little importance }\end{array}$ & $\begin{array}{c}50(40.3) \\
72(58.1) \\
1(0.8) \\
1(0.8)\end{array}$ & $\begin{array}{c}16(45.7) \\
18(51.4) \\
0(0) \\
1(2.9)\end{array}$ & $\begin{array}{c}34(38.2) \\
54(60.7) \\
1(1.1) \\
0(0)\end{array}$ & 0.173 \\
\hline $\begin{array}{l}\text { Do you feel that your current knowledge about Public Health Programs } \\
\text { is sufficient? } \\
\text { Very much sufficient } \\
\text { Sufficient } \\
\text { Not sufficient } \\
\text { Totally insufficient }\end{array}$ & $\begin{array}{c}1(0.8) \\
22(17.7) \\
95(76.6) \\
6(4.8)\end{array}$ & $\begin{array}{c}1(2.9) \\
9(25.7) \\
23(65.7) \\
2(5.7)\end{array}$ & $\begin{array}{c}0(0) \\
13(14.6) \\
72(80.9) \\
4(4.5)\end{array}$ & 0.163 \\
\hline $\begin{array}{l}\text { Do you feel have an important role to play in Public Health Programs? } \\
\text { Very important } \\
\text { Important } \\
\text { Unimportant } \\
\text { Of little importance }\end{array}$ & $\begin{array}{c}32(25.8) \\
80(64.5) \\
7(5.6) \\
5(4)\end{array}$ & $\begin{array}{c}8(22.9) \\
25(71.4) \\
2(5.7) \\
0(0)\end{array}$ & $\begin{array}{c}24(27) \\
55(61.8) \\
5(5.6) \\
5(5.6)\end{array}$ & 0.477 \\
\hline $\begin{array}{l}\text { Have you ever taken part in a any Public Health Program(s) during } \\
\text { your pharmacy education? } \\
\text { Yes } \\
\text { No }\end{array}$ & $\begin{array}{l}30(24.2) \\
94(75.8)\end{array}$ & $\begin{array}{l}11(31.4) \\
24(68.6)\end{array}$ & $\begin{array}{l}19(21.3) \\
70(78.7)\end{array}$ & 0.238 \\
\hline $\begin{array}{l}\text { During your internship, have you ever taken part in any Public Health } \\
\text { Program(s)? } \\
\text { Yes } \\
\text { No }\end{array}$ & $\begin{array}{c}20(16.1) \\
104(83.9)\end{array}$ & $\begin{array}{c}7(20) \\
28(80)\end{array}$ & $\begin{array}{l}13(14.6) \\
76(85.4)\end{array}$ & 0.462 \\
\hline $\begin{array}{l}\text { Would you like to take on professional role in Public Health Program? } \\
\text { Yes } \\
\text { No }\end{array}$ & $\begin{array}{c}121(97.6) \\
3(2.4)\end{array}$ & $\begin{array}{c}33(94.3) \\
2(5.7)\end{array}$ & $\begin{array}{c}88(98.9) \\
1(1.1)\end{array}$ & 0.134 \\
\hline $\begin{array}{l}\text { Are you willing to learn or learn more about Public Health Programs in } \\
\text { your pharmacy curriculum? } \\
\text { Yes } \\
\text { No }\end{array}$ & $\begin{array}{c}122(98.4) \\
2(1.6)\end{array}$ & $\begin{array}{c}35(100) \\
0(0)\end{array}$ & $\begin{array}{c}87(97.8) \\
2(2.2)\end{array}$ & 0.371 \\
\hline
\end{tabular}

Table 4 shows that $58.1 \%$ of respondents think that National Public Health Programs should be included in curriculum of pharmacy education programs (Table 4). The highest proportion of students who have been involved in national health programs during pharmacy education programs are Pharmacy Diploma Program students of $31.4 \%$. As many as $97.6 \%$ of students expressed willingness to take up professional roles in national health programs and $98.4 \%$ wanted to learn more about national health programs.

The study results revealed that there is no relationship between pharmacy education programs group (Pharmacy Diploma Program and Pharmacy Bachelor Program) towards attitude in National Health Programs (pvalue $>0.05$ ). This research shows students have a positive overview and assume that pharmacist need to be involved in National Health Programs. The pharmacy students involved in this study are willing to learn more and take on professional role in Indonesia's National Health Programs during their pharmacy education, where pharmacy technician and pharmacists are could contribute. Therefore, needs to be an improvement in their curriculum to increase student's knowledge and support their awareness to take on professional roles in national health programs. This study is supported by research from Prasada which states that pharmacists play an professionals role and need to be supported to take part in National Health Programs [10]. Increasing information about public health services will have a positive effect of the attitudes and increase their knowledge.

\section{CONCLUSION}

One of the government's efforts to overcome health problems is through the National Health Programs activity and the pharmacists have an important role in disseminating the National Health Programs to community. Health education institutions as the pioneer of health workers must equip their students with sufficient knowledge about national health programs so as to increase their role and 
[4] R. Ilham and nurfatwa I. Ilham, "The Implementation of GERMAS ( Healthy Life Movement ) in Senior Citizens With Degenarative Diseases," Eur. J. Public Heal. Stud., vol. 1, no. 2, pp. 79-89, 2019.

[5] Sarmalina, Sarmadi, M. Rahmi, and S. Mangunsong, "Peningkatan Kapasitas Ibu-Ibu Arisan Sebagai Inisiator Gerakan Masyarakat Cerdas Menggunakan Obat (Gema Cermat)," Link, vol. 15, no. 1, p. 3641, 2019.

We gratefully thank to the principal of Faculty of Health Science Universitas Muhammadiyah Magelang for allowing me to conduct the research there.

\section{REFERENCES}

[1] E. S. Sulaeman, R. Karsidi, B. Murti, D. T. Kartono, Waryana, and R. Hartanto, "Community Empowerment Model in Health Sector, Study on Village Preparadness Program," J. Kesehat. Masy. Nas., vol. 7, no. 4, pp. 186-192, 2012.

[2] A. D. Yuniar and A. S. Fibrianto, "Public Health Communication Campaign ' Germas' by Ministry of Health in Maluku 2018 :,” Adv. Soc. Sci. Educ. Humanit. Res., vol. 343, pp. 152-156, 2019.

[3] Patonah, L. Marliani, and Y. Mulyani, "Edukasi Pola Hidup Sehat Kepada Masyarakat Di Kelurahan Manjahlega Kota Bandung Dalam Menanggulangi Obesitas Sebagai Faktor Resiko Penyakit Kardiovaskular," J. Pengabdi. Kpd. Masy., vol. 3, no. 2, pp. 1-8, 2019.
[6] M. Rahmadiana, "Komunikasi Kesehatan : Sebuah Tinjauan*," J. Psikogenes., vol. 1, no. 1, pp. 88-94, 2012.

[7] M. Ulfa and Junaidi, "Perencanaan Komunikasi Fasilitator Kesehatan Dalam Program Gerakan Masyarakat Hidup Sehat (GERMAS)," J. War. Ed., vol. 58, pp. 1-24, 2018.

[8] S. U. Chasanah, "Peran Petugas Kesehatan Masyarakat Dalam Upaya Penurunan Angka Kematian Ibu Pasca MDGs 2015,” J. Kesehat. Masyrakat Andalas, vol. 9, no. 2, pp. 73-79, 2015.

[9] W. A. S. Tamnge and M. Munir, "Health Personnel Services with Routine Medical Examination on GERMAS Program in Sukolilo Tuban," Prodi S1 Keperawatan STIKES Nahdlatul Ulama Tuban, pp. 19, 2018.

[10] S. Prasada, R. Maddirala, P. Kielgast, and U. Udhumansha, "Role of Pharmacists in National Public Health Programs in India : A Survey on Pharmacy Students 'Perceived Knowledge and Attitude," Indian J. Pharm. Educ. Res., vol. 50, no. 1, pp. 51-62, 2016. 